\title{
PENINGKATAN HASIL BELAJAR IPA MELALUI MODEL PEMBELAJARAN PROBLEM BASED INTRODUCTION PADA SISWA KELAS II SD INPRES BONTOCINIAYO
}

\author{
Muliati \\ Guru SDI Bontociniayo \\ Email: muliati.sdbontociniayo@gmail.com
}

\begin{abstract}
This research is a classroom action research that aims to improve the learning outcomes of class II SDI Bontociniayo through the use of the Problem Based Introduction (PBI) method. The subject of this study was class II SDI Bontociniayo with 26 students consisting of 15 female students and 11 male students.

This research was conducted in two cycles, namely the first cycle was carried out 2 times and the second cycle was also conducted two meetings, which were conducted for 2 months. The result is an increase in student learning outcomes through the Problem Based Introduction (PBI) method is (i) The level of learning outcomes of class II SDI Bontociniayo in the first cycle included in the high category with an average value of 68.2 while in the second cycle progressed with the category very high with an average value of 77.4, (ii) There is an increase in the learning outcomes of class II SDI Bontociniayo through the application of the Problem Based Introduction (PBI) method, both qualitatively and quantitatively. This can be seen in the table and explanation in the attachment, in the first cycle and second cycle of each action starting from action I to action II.

In connection with the above results, the learning model is considered to be quite effective in teaching especially in the field of science studies, because it can improve student learning outcomes both in doing their assignments in school and providing opportunities for students to always try (experiment) in each activity learning so that they can be more motivated to achieve maximum achievement.
\end{abstract}

Keywords: Problem Based Instruction, Science Learning Outcomes

\section{PENDAHULUAN}

\section{A. Latar Belakang}

I

lmu Pengetahuan Alam (IPA) merupakan salah satu disiplin ilmu yang berhubungan dengan cara mencari tahu tentang alam secara sistematis, sehingga IPA bukan hanya penguasaan kumpulan pengetahuan berupa fakta-fakta, konsep-konsep, atau prinsipprinsip saja tetapi juga merupakan suatu proses penemuan, sehingga dapat membantu peserta didik memperoleh pengalaman langsung dan pemahaman untuk mengembangkan kompetensinya agar dapat menjelajahi dan memahami alam sekitar secara ilmiah.

Berdasarkan observasi dilapangan adanya temuan bahwa kedudukan dan fungsi guru dalam kegiatan pembelajaran saat ini cenderung masih dominan. Aktifitas guru 
masih sangat besar dibandingkan dengan aktifitas siswa yang masih rendah kadarnya. Ketika proses belajar mengajar hendaknya terjalin hubungan yang sifatnya mendidik dan mengembangkan. Guru tidak hanya menyampaikan materi akan tetapi sebagai figur yang dapat merangsang perkembangan siswa.

Pertanyaan yang timbul adalah bagaimana upaya guru menciptakan pembelajaran yang optimal dengan komunikasi multi arah, meningkatkan aktifitas, meningkatkan penguasaan konsep, meningkatkan kemampuan pemecahan masalah, dan meningkatkan hasil belajar siswa?

Sehubungan dengan hal di atas model pembelajaran yang digunakan oleh guru hendaknya sedemikian rupa bervariasi sesuai dengan tujuan dan materi yang diajarkan. Dengan model pembelajaran yang variatif inilah siswa akan bergairah dalam belajar secara inovatif dan kreatif. Model pembelajaran yang digunakan guru dalam interaksi belajar mengajar merupakan salah satu faktor yang menentukan keberhasilan dan kelancaran proses pembelajaran.

Salah satu model pembelajaran yang dimaksud adalah model Problem Based Introduction yang dapat memberikan pengalaman kongkret, memotivasi, serta mempertinggi daya serap dan daya ingat siswa dalam pembelajaran yang berdasar pada sebuah permasalahan. Alasan digunakannya model ini dalam proses pembelajaran karena dapat merangsang kemampuan daya ingat anak serta merangsang kreativitas guru dan siswa sehingga dapat meningkatkan Prestasi belajar IPA siswa dari masalah yang dialami.

\section{B. Rumusan Masalah}

Berdasarkan deskripsi latar belakang masalah yang telah diuraikan, maka rumusan masalah dalam penelitian ini adalah "Apakah melalui model pembelajaran Problem Based Introduction hasil belajar IPA siswa kelas II SDI Bontociniayo dapat meningkat?”

\section{Tujuan Penelitian}

Sesuai dengan rumusan masalah di atas, maka penelitian ini bertujuan untuk mengetahui peningkatan hasil belajar siswa kelas II SDI Bontociniayo setelah guru menerapkan model Problem Based Introduction dalam pembelajaran IPA.

\section{KAJIAN PUSTAKA}

\section{A. Model Pembelajaran}

Model pembelajaran adalah suatu disain yang menggambarkan proses rincian dan penciptaan situasi lingkungan yang memungkinkan siswa berinteraksi sehingga terjadi perubahan atau perkembangan pada diri siswa.

\section{B. Definisi Model Pembelajaran Berdasarkan Masalah (Problem Based Introduction)}

Model ini memusatkan pada masalah kehidupannya yang bermakna bagi siswa, peran guru menyajikan masalah, mengajukan pertanyaan dan memfasilitasi penyelidikan dan dialog. 
Langkah-langkah :

a. Guru menjelaskan tujuan pembelajaran, menjelaskan sarana yang dibutuhkan memotivasi siswa untuk terlibat dalam aktivitas pemecahan masalah yang di pilih

b. Guru membantu siswa merumuskan dan mengorganisasikan tugas yang berhubungan dengan masalah yang dipilih (menetapkan topik, tugas, jadwal, dan lain-lain).

c. Guru memantau siswa untuk mengumpulkan informasi yang diperlukan, melaksanakan eksperimen atau penelitian untuk mendapat data yang akurat, pengumpulan data, analisa data untuk menguji hipotesa, atau mendeskripsikan temuan yang diperoleh (refleksi, atau evaluasi) terhadap penelitian yang mereka rencanakan.

d. Guru membantu siswa dalam menyusun laporan dan membantu mereka berbagi tugas dengan temannya.

Problem-based instruction adalah model pembelajaran yang berlandaskan paham konstruktivistik yang mengakomodasi keterlibatan siswa dalam belajar dan pemecahan masalah otentik.

\section{Pembelajaran IPA}

Pembelajaran Ilmu Pengetahuan Alam sebagai adalah sebagai suatu pendekatan yang menggunakan cara bagaimana atau jalan apa yang harus ditempuh oleh murid dengan bimbingan guru untuk sampai pada penemuan-penemuan dan bukan penemuan itu sendiri. Dalam pendekatan inkuiri Ilmu Pengetahuan Alam, yaitu pertama membuat perumusan hipotesis, kedua menguji hipotesis itu.

\section{Hasil Belajar}

\section{a. Pengertian Hasil Belajar}

Hasil belajar merupakan segala sesuatu yang diperoleh, dikuasai atau merupakan hasil proses belajar mengajar. Hasil belajar merupakan kemampuan yang dimiliki siswa setelah ia menerima pengalaman belajar.

\section{b. Faktor-faktor yang Mempengaruhi Hasil Belajar}

Menurut Tabrani (dalam Darmadji, 2007:31) bahwa faktor-faktor yang mempengaruhi suksenya belajar adalah:

1. Faktor internal yang terdiri atas:
a. Faktor jasmani
b. Faktor psikologis (itelektual dan non intelktual)
c. Faktor kematangan psikis dan fisik

2. Faktor eksternal yang meliputi:
a. Faktor sosial (keluarga, sekolah, dan masyarakat)
b. Faktor budaya (seni, ilmu, dan teknologi),
c. Faktor lingkungan (spritual dan lingkungan) 


\section{METODE PENELITIAN}

\section{A. Setting Penelitian}

\section{Waktu Penelitian}

Penelitian ini berlangsung pada bulan September sampai Oktober 2016 selama 6 minggu. bulan September dan Oktober tahun pelajaran 2016/2017 dipilih karena waktu tersebut diperkirakan untuk memberikan materi energy.

\section{Tempat Penelitian}

Penelitian ini dilaksanakan di kelas II SDI Bontociniayo. Subjek penelitian adalah siswa kelas II SDI Bontociniayo pada semester ganjil tahun pelajaran 2016/2017.

\section{B. Subjek Penelitian}

Adapun subjek penelitian ini adalah siswa kelas II yang berjumlah 26 siswa yang terdiri dari 11 laki-laki dan 15 perempuan.

\section{Sumber Data}

Sumber data dalam penelitian tindakan kelas ini adalah seluruh siswa kelas II SDI Bontociniayo dan guru kelas yang mengajar IPA. Data siswa yang diambil berupa tes hasil belajar, keaktifan siswa dan iteraksi antara guru dengan siswa dalam proses belajar mengajar siswa serta kegiatan mengajar guru.

\section{Teknik dan Alat Pengumpulan Data}

1. Teknik pengumpulan data
a. Tes
b. Observasi

2. Alat pengumpulan data
a. Butir soal tes
b. Lembar observasi siswa
c. Lembar observasi guru

\section{E. Validitas Data}

validasi data dilakukan oleh teman kolaborasi atau teman kelompok. Validasi ini dilakukan terhadap materi ajar, silabus, RPP, butir-butir soal yang telah disediakan maupun lembaran soal dan model pembelajaran termasuk lembar observasi.

\section{F. Analisis Data}

Analisis data menggunakan analisis deskriptif atau prosentase dengan membandingkan hasil tes dan observasi pada siklus I dengan hasil tes dan observasi pada siklus II.

\section{G. Indiator Kinerja}

Indikator keberhasilan dalam penelitian ini adalah apabila telah terbentuk keterampilan sosial dalam diri siswa baik kerjasama dalam kelompok maupun dalam memberikan tanggapan. Selain itu, terjadi peningkatan hasil yang menyangkut skor rata- 
rata hasil tes belajar siswa kelas II SD SDI Bontociniayo, ditandai dengan meningkatkan jumlah siswa yang sudah mencapai ketuntasan individu maupun klasikal. Menurut ketuntasan DIKNAS siswa dikatan tuntas belajar apabila memperoleh skor $65 \%$ dari skor ideal, dan tuntas klasikal apabila $85 \%$ dari jumlah siswa yang tuntas belajar secara individual.

\section{H. Prosedur Penelitian}

Penelitian tindakan kelas ini dilaksanakan sebanyak dua siklus. Setiap siklus I terdiri atas 3 kali pertemuan ( 6 x35 menit), yaitu 2 kali pertemuan (4x35 menit) untuk tatap muka dan 1 kali pertemuan $(2 \times 35$ menit $)$ untuk evaluasi hasil belajar. Setiap pertemuan dilaksanakan dalam 2x35 menit. Pada setiap siklus dilakukan perubahan tindakan sesuai dengan tujuan yang ingin dicapai.

\section{SIKLUS I}

a. Perencanaan

1. Menelaah kurikulum kelas II SDI Bontociniayo semester ganjil tahun pelajaran 2016/2017 pada mata pelajaran IPA.

2. Berdiskusi dengan guru mata pelajaran IPA kelas II SDI Bontociniayo dan membuat rencana pelaksanaan pembelajaran (RPP dengan mengguanakn model pembelajaran Problem Based Introduction.

3. Membuat lembar observasi untuk melihat keaktifan siswa selama tindakan berlangsung.

4. Membuat tes hasil belajar belajar tentang pengertian pembelajarn IPA

b. Pelaksanaan tindakan

Adapun tahap-tahap pelaksanaan tindakan pada siklus I ini adalah sebagai berikut.

1. Pengelolaan kelas, yaitu pembagian kelompok, pengaturan atau setting kelas, serta absensi siwa

2. Kegiatan awal pembelajaran yaitu penjelasan tentang pembelajaran, apersepsi, proses untuk mencari gambaran pemahaman siswa tentang materi yang diajarkan (menunjuk beberapa siswa untuk menjelaskan atau menjawab pertanyaan.

3. Kegiatan inti yaitu pembentukan kelompok belajara, guru menjelaskan materi lalu membimbing siswa menyelesaikan evaluasi secara berkelompok setelah itu diadakan evaluasi dengan melihat hasil persentase kelompok dan memberikan penghargaan baik secara tim maupun individu

4. Kegiatan akhir penyimpulan materi ajar dan diakhiri dengan evaluasi yaitu menjawab instrument penelitian.

c. Observasi dan Evaluasi

Pada prinsipnya tahap observasi dilakukan selama penelitian berlangsung yang terdapat pada lembar observasi yang meliputi: kehadiran siswa, siswa yang melakukan kegiatan lain pada saat pembelajaran, siswa yang aktif pada saat 
pembelajaran, memerhatikan guru, dan lain-lain. Pada akhir tindakan siklus I, melaksanakan evaluasi untuk mengetahui hasil belajar siswa.

d. Refleksi

Refleksi dilakukan pada akhir siklus. Hasil yang diperoleh pada tahap observasi dikumpulkan, tes belajar siswa. Hasil analisis siklus pertama inilah yang dijadikan acuan penulis untuk merencanakan siklus kedua. Hal-hal yang belum berhasil ditindaklanjuti sedangkan yang sudah baik dipertahankan atau ditingkatkan, sehingga hasil yang dicapai pada siklus berikutnya sesuai dengan yang diharapkan dan hendaknya lebih baik dari siklus sebelumnya.

\section{SIKLUS II}

a. Pengamatan

Penelitian ini dilakukan secara kolaboratif dengan guru IPA lainnnya. Pengamatan dilakukan dalam proses pembelajaran dengan menggunakan lembar observasi. Data berupa hasil observasi kebiatan guru dan keaktifan siswa, sedangkan prestasi siswa dijaring melalui tes formatif kemudian dibandingkan dengan hasil tes awal.

b. Refleksi

Data yang dikumpulkan pada siklus pertama dianalisis, didiskusikan dengan para observer kemudian dideskripsikan. Hasilnya dijadikan sebagai bahan perencanaan untuk melaksanakan tindakan yang dimodifikasi dari siklus sebelumnya guna mencapai hasil yang baik.

\section{HASIL PENELITIAN DAN PEMBAHASAN}

\section{A. Hasil Penelitian}

Penyajian berikut ini dikelompokkan menjadi 2 bagian yaitu hasil analisis secara kualitatif dan kuantitatif penyajian data kualitatif memaparkan data kualitatif data proses pembelajan yang terjadi di kelas selama penelitian berlangsung dan data kuantitatif bertujuan memaparkan data nilai prestasi belajar siswa.

\section{Analisis Kualitatif dan Kuantitatif Hasil Belajar IPA Siswa Kelas II SDI} Bontociniayo melalui Penerapan Model Pembelajaran Problem Based Introduction (PBI) Siklus I

a. Perencanaan

1. Melakukan diskusi dengan guru mata pelajaran IPA pada sekolah lokasi penelitian untuk membahas masalah yang akan dipecahkan.

2. Menkaji kurikulum materi pelajaran IPA II SDI Bontociniayo yang akan diajarkan pada penelitian ini.

3. Menentukan pokok bahasan yang akan diajarkan

4. Mempersiapkan perangkat pembelajaran yakni RPP

5. Membuat format observasi untuk melihat bagaimana kondisi belajar mengajar di kelas. 
b. Pelaksanaan

Pelaksanaan pembelajaran IPA dilakukan selama 2 kali pertemuan, setiap pertemuan dilakukan tahap-tahap berikut ini:

1. Guru membuka pelajaran

2. Guru melakukan apersepsi

3. Dilakukan pembelajaran IPA melalui penerapan model pembelajaran Problem Based Introduction (PBI).

4. Pemberian tugas untuk mengetahui pencapaian indikator hasil belajar setelah proses pembelajaran

5. Pemberian PR untuk melatih murid mengerjakan tugas

6. Perbaikan jawaban murid terhadap indikator yang belum dicapai di atas suatu tugas yang diberikan sampai indikator tersebut tercapai dan menuliskan komentar tentang kekurangan dalam kelebihan murid terhadap tugas yang dikerjakan.

7. Tiap pertemuan guru mencatat semua kejadian yang dianggap penting seperti kehadiran murid dan keaktifan murid mengikuti pelajaran.

c. Observasi

Berdasarkan hasil observasi diperoleh gambaran bahwa:

1. Siswa yang menyimak dan memperhatikan pengarahan guru dikategorikan sedang.

2. Siswa memberikan tanggapan dan mengajukan pertanyaan atas masalah dikategorikan rendah

3. Siswa menjawab pertanyaan dengan benar dan tepat dikategorikan sangat rendah

4. Siswa yang aktif mencari pemecahan masalah dikategorikan sangat rendah

d. Refleksi

Berdasarkan hasil observasi rekan guru dan tanggapan /masukan mengenai penggunaan metode pengajaran ini, maka perlu dibenahi adalah:

1. Penguatan dan motivasi yang diberikan kepada siswa perlu ditingkatkan

2. Struktur kelas perlu diubah yaitu dengan membentuk tutor yang bisa membimbing temannya agar setiap siswa (individu) dapat termotivasi belajar dan prestasi belajar bisa meningkat

3. Kesulitan siswa memahami perlu mendapat bimbingan dari guru

4. Kesulitan siswa memanfaatkan penggunaan metode pembelajaran inquiry perlu atau dapat bimbingan dari gur

5. Pengguanaan model pembelajaran Problem Based Introduction (PBI) dalam pembelajaran berwujud pengamatan, eksperimen, dan diskusi permainan serta pemahaman yang bermakna.

6. Guru harus memberikan pujian bagi siswa yang berprestasi. 
Dari gambaran proses pembelajaran di atas maka peneliti memperoleh data bahwa nilai rata-rata hasil belajar siswa pada siklus I adalah 68.2.

2. Analisis Kualitatif dan Kunatitatif Hasil Belajar IPA Siswa Kelas II SDI Bontociniayo melalaui penerapan model pembelajaran Problem Based Introduction (PBI) Siklus II

a. Perencanaan

1. Melakukan diskusi dengan guru mata pelajaran bidang studi IPA pada sekolah penelitian untuk membahas masalah yang ditemukan di siklus I dan memahami solusinya

2. Menentukan pokok bahasan yang diajarkan

3. Mempersiapkan perangkat pembelajaran, yakni RPP

4. Membuat format observasi untuk melihat bagaimana kondisi belajar mengajar di kelas

b. Pelaksanaan

Pelaksanaan pembelajaran IPA dilakukan secara dua kali pertemuan, setiap pertemuan dilakukan melalui tahap-tahap berikut ini:

1. Guru membuka pelajaran

2. Guru melakukan apersepsi

3. Guru menyampaikan materi

4. Guru membentuk kelompok

5. Dilakukan pembelajaran IPA melalui penerapan model pembelajaran Problem Based Introduction (PBI) dalam kegiatan ini

6. Dalam penerapan model pembelajaran Problem Based Introduction (PBI) ini dilakukan dalam wujud pengelompokan dan mengangkat sebuah permasalahan dalam pembelajaran secara adil dan obyektif

7. Pemberian tugas untuk mengetahui pencapaian indikator hasil belajar serta proses pembelajaran

8. Pemberian PR untuk melatih siswa mengerjakan tugas

c. Observasi

1. Siswa yang menyimak dan memperhatikan pengarahan guru dikategorikan tinggi

2. Siswa memberikan tanggapan dan mengajukan pertanyaan atas masalah dikategorikan tinggi

3. Siswa yang menjawab pertanyaan dengan benar dan tepat dikategorikan tinggi

4. Siswa yang aktif mencari pemecahan masalah dikategorikan tinggi

5. Kerajinan siswa mencari pemahaman masalah dikategorikan tinggi

6. Respon siswa terhadap materi dikategorikan tinggi 
d. Refleksi

Kegiatan siswa pada siklus II ini, semangat dan perhatian siswa dalam proses pembelajaran ini meningkat. Hal ini terlihat dari perhatian serius dari siswa dalam menanggapi materi. Sikap positif siswa dalam memberikan tanggapan atau respon terhadap materi yang disajikan.

Dari gambaran proses pembelajaran di atas maka peneliti memperoleh data bahwa nilai rata-rata hasil belajar siswa pada siklus II adalah 77.4.

\section{B. Pembahasan Hasil Penelitian}

Berdasarkan hasil analisis kuantitatif dan kualitatif, terlihat bahwa pada dasarnya melalui penerapan model pembelajaran Problem Based Introduction (PBI) meningkatkan hasil belajar IPA. Untuk menumbuhkan dan meningktakan hasil belajar IPA siswa dengan penerapan model pembelajaran Problem Based Introduction (PBI), maka guru harus menerapkan hal berikut ini.

1. Apersepsi dan pemberian motivasi belajar

2. Guru harus mengidentifikasi masalah siswa secara menyeluruh dan membantu menyelesaikannya

3. Guru harus membantu dan mengarahkan siswa melalui penerapan metode pembelajaran Problem Based Introduction (PBI) dalam pembelajaran untuk memudahkan memahami materi

4. Guru harus memberikan gambaran bahwa siswa yang aktif dalam belajar dalam kaitannya dengan kehidupan lingkungan yang ada disekitar dan kehidupan yang akan datang

5. Guru harus memberikan gambaran kepada siswa tentang kegunaan belajar dalam kaitannya dengan kehidupan yang akan datang.

Melalui penerapan hal tersebut, dapat meningkatkan hasil belajar siswa. Hal-hal yang tampak mengalami peningkatan pada siswa jika guru melalui penerapan model pembelajaran Problem Based Introduction (PBI) yaitu:

1. Rata-rata siswa menyimak dan memperhatikan pengarahan guru

2. Siswa memberikan tanggapan dan mengajukan pertanyaan atas masalah yang diajukan oleh guru dan berusaha menemukan jawaban dari pertanyaan yang siswa dapat sendiri

3. Siswa menjawab pertanyaan dengan benar dan tepat

4. Siswa aktif mencari pemecahan masalah

5. Kerajinan siswa membaca dan mengerjakan tugas

6. Respon siswa yang tinggi terhadap materi

Peningkatan hasil belajar siswa dengan penerapan model pembelajaran Problem Based Introduction (PBI) tersebut merupakan hal mutlak. Hal ini dinyatakan sebab melalui penerapan model pembelajaran Problem Based Introduction (PBI) yang diterapkan dalam pembelajaran IPA dinilai oleh siswa sangat menarik. melalui penerapan 
model pembelajaran Problem Based Introduction (PBI itu juga dianggap sebagai model pembelajaran berkelompok sehingga siswa bersemangat dalam belajar.

Siswa SD I Bontociniayo pada dasarnya memiliki kesenangan belajar yang berbasis perkelompok atau bekerja sama dengan orang lain setelah mengamati, eksperimen dan diskusi terhadap materi yang diajarkan oleh peneliti yaitu energi karena memang segala aktivitas sehari-hari siswa kelas II. Oleh karena itu, peningkatan prestasi belajar dapat dilakukan dengan metode pembelajaran berbasis perkelompok atau bekerja sama untuk mendapatkan hasil yang maksimal.

\section{KESIMPULAN}

Berdasarkan hasil penelitian tindakan kelas yang telah dilaksanakan dalam 2 siklus di SDI Bontociniayo dapat disimpulkan bahwa melalui penerapan model pembelajaran Problem Based Introduction (PBI) dapat meningkatkan hasil belajar IPA siswa kelas II SDI Bontociniayo tahun ajaran 2016/2017.

\section{DAFTAR PUSTAKA}

Ahmadi Ali, M. (2004). Guru dalam Proses Belajar Mengajar. Bandung: Sinar Baru Algesindo di. Abu. 1997. Strategi Belajar Mengajar. Bandung: Pustaka Setia

Arikunto, S. 2008. Prosedur Penelitian "Suatu Pendekatan Praktik". Edisi Revisi VI. Jakarta: PT. Rineka Cipta.

BSNP. 2006. Standar Isi Kurikulum Tingkat Satuan Pendidikan (KTSP) : Jakarta

CV Mini Jaya Abadi. 2006. Kriteria Ketuntasan Minimal (KKm). Jakarta: Depdikbud.

Depdiknas. 2006. Standar Kompetensi dan Kompetensi Dasar Mata Pelajaran IPA. Jakarta: Depdikbud.

Dimyati, dan Mudjiono. 1992. Belajar Dan Pembelajaran. Jakarta : Proyek Pembinaan dan Peningkatan Mutu Tenaga Kependidikan Depdikbud.

Hasibun, J \& Moedjiono. 2006. Proses Belajar Mengajar. Bandung: PT. Remaja Rosdakarya.

Www.idtesis.blogspot.com

wyw1d. Wordpress. Com. Pembelajaran.

www. Docstoc. Com. Education college.

Kasbolah, K. (1998). Penelitian Tindakan Kelas. Jakarta: Departemen Pendidikan dan Kebudayaan, Direktorat Jendral Pendidikan Dasar dan Menengah Bagian Proyek Penataran Guru SLTP setara DIII.

Nasution, N. (2005). Pendidikan IPA di SD. Jakarta: Universitas Terbuka. 
Sardiman, A. M. 2007. Interaksi \& Motivasi Belajar Menagajar. Jakarta: PT. Raja Grafindo Persada.

Surya Subroto. 2002. Proses Belajar Mengajar. Bandung: PT Remaja.

Sujana, N. Dkk. (2004). Penelitian dan Penilaian Pendidikan. Bandung: Sinar Baru Algesindo.

Trianto. 2007, Model-Model Pembelajaran Inovatif Berorientasi Konstruksik Jakarta: Prestasi Pustaka pulisher.

Uno, Hamzah B. 2007. Teori Motivasi dan Pengukurannya "Analisis di Bidang Pendidikan”. Jakarta: Bumi Aksara 